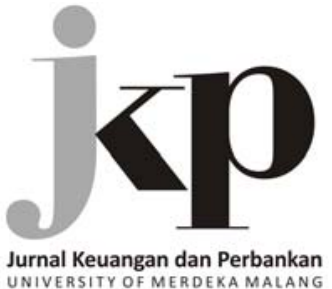

Article history:

Received: 2018-08-29

Revised: 2018-09-20

Accepted: 2018-10-16
Ratna Dewi Tjendani ${ }^{1}$, Ari Kuncara Widagdo ${ }^{2}$, Muthmainah Muthmainah ${ }^{2}$

${ }^{1}$ Master of Accounting, Faculty of Economics and Business, Universitas Sebelas Maret ${ }^{2}$ Department of Accounting, Faculty of Economics and Business, Universitas Sebelas Maret

JI. Ir Sutami No. 36-A Surakarta, 57126, Indonesia

$\triangle$ Corresponding Author:

Ratna Dewi Tjendani:

Tel +62 271647481

E-mail: ratna.dewi.tjendani@gmail.com

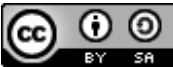

This is an open access article under the CC-BY-SA license

\author{
Ratna Dewi Tjendani(Indonesia), Ari Kuncara Widagdo (Indonesia), \\ Muthmainah Muthmainah (Indonesia)
}

\section{Digital Banking, Corporate Governance, Ownership Structure, and Intellectual Capital Performance: Evidence from Indonesia}

\begin{abstract}
The base of the company's growth has changed, from tangible assets to intangible assets. Many companies recognize the importance of IC as performance drivers. This research aimed to examine the effect of the implementation of digital banking, corporate governance, family ownership, foreign ownership, and government ownership on Intellectual Capital (IC) performance; and examined the effect of interactions between corporate governance and ownership structure on IC performance in banking companies listed on the Indonesia Stock Exchange (IDX) during 20122016. This research used a regression method with panel data. The total observations were 130 cases. In this research, IC performance used Value Added Intellectual Coefficient (VAIC). We proved that the implementation of digital banking did no significant implications for IC performance in the same year because it was still in the process of developing. Family ownership, foreign ownership, government ownership, and the interaction between corporate governance and ownership structure did not affect IC performance. On the contrary, this research proved that corporate governance had significant implications for improving IC performance.
\end{abstract}

Keywords: Corporate Governance; Digital Banking; Intellectual Capital Performance; Ownership Structure

\section{JEL Classification: G31, G32, G34}

Citation: Tjendani, R. D., Widagdo, A. K., \& Muthmainah, M. (2018). Digital banking, corporate governance, ownership structure, and intellectual capital performance: Evidence from Indonesia. Jurnal Keuangan dan Perbankan, 22(4), 714-733. https://doi.org/10.26905/jkdp.v22i4.2481

\begin{abstract}
Abstrak
Basis pertumbuhan perusahaan telah berubah, dari aset berwujud menjadi aset tidak berwujud. Banyak perusahaan mengakui pentingnya IC sebagai driver kinerja.Penelitian ini bertujuan untuk menguji pengaruh penerapan perbankan digital, tata kelola perusahaan, kepemilikan keluarga, kepemilikan asing dan kepemilikan pemerintah terhadap kinerja Intellectual Capital (IC) dan menguji pengaruh interaksi antara tata kelola perusahaan dan struktur kepemilikan terhadap kinerja IC pada perusahaan perbankan yang terdaftar di Bursa Efek Indonesia (BEI) selama 2012-2016. Penelitian ini menggunakan metode regresi dengan data panel. Total pengamatan adalah 130 kasus. Dalam penelitian ini, kinerja IC menggunakan Value Added Intellectual Coefficient (VAIC). Kami membuktikan bahwa penerapan perbankan digital tidak berimplikasi signifikan terhadap IC performance pada tahun yang sama karena masih dalam proses berkembang. Kepemilikan keluarga, kepemilikan asing, kepemilikan pemerintah, dan interaksi antara tata kelola dan struktur kepemilikan tidak berpengaruh terhadap IC performance. Sebaliknya, penelitian ini membuktikan bahwa tata kelola perbankan berimplikasi signifikan dalam meningkatkan IC performance.
\end{abstract}

Kata Kunci: Tata Kelola; Perbankan Digital; Kinerja Modal Intelektual; Struktur Kepemilikan 
The development of the modern era caused a change in economic development (Osinski et al., 2017). The change of industrial economics marks the change in economic development into knowledge-based economics, an economic development that prioritizes knowledge capital in its activities (Schiavone et al., 2014). The most advanced economic growth in the recent year is knowledge-based economics (Dzenopoljac et al., 2017). Knowledge becomes an important element of economic resources and a source of competitive advantage (Usoff, Thibodeau, \& Burnaby, 2002; Hamdan, 2018).

Along with these changes, the base of the companies growth also changes, from tangible assets to intangible assets (Osinski et al., 2017; Rochmadhona, Suganda, \& Cahyadi, 2018). Al-Musali \& Ismail (2016) argue that the emergence of a knowledge-based economy basically driven by intangible assets has increased interest in Intellectual Capital (IC). According to the Chartered Institute of Management Accountants (2000), IC is the possession of knowledge and experience, professional knowledge and skills, good relationships, and technological capacity, which can provide a competitive advantage for the company. Thus, IC is the most important intangible asset for companies in creating value, replacing machinery and natural resources (Daryaee et al., 2011).

Today, many companies recognize the importance of IC as performance drivers (Marr \& Moustaghfir, 2005; Ozkan, Cakan, \& Kayacan, 2017). In the new economic era, IC serves as knowledgerelated resources, representing the wealth of ideas, capabilities, infrastructure, and relationships that are the most important factors for business success in creating value and sustaining a company's competitive advantage (El-Bannany, 2012; Al-Musali \& Ismail, 2016; Kehelwalatenna, 2016; Khairiyansyah \& Vebtasvili, 2018). In many instances, IC is important for decision making within the company and external interests (Alhassan \& Asare, 2016).

In recent years, the banking industry is facing a competitive environment (Mondal \& Ghosh,
2012; Alhassan \& Asare, 2016). Cross-border competition is forcing the banking industry to achieve sustainable financial performance (Mondal \& Ghosh, 2012). The banking industry is a knowledge-intensive industry with technological innovation and high customer interaction (Veltri \& Silvestri, 2011). Therefore, it is important for banks to invest in the development of intellectual potential for sustainable competitive advantage (Tiwari \& Vidyarthi, 2018).

Although many research states the importance of IC in the creation of corporate value and requires appropriate measurement tools, traditional financial accounting still does not take into account intangible resources that drive corporate value (Abhayawansa \& Guthrie, 2016). Under International Accounting Standards (IAS 38), most intangible assets cannot be identified unless the assets protected by certain laws (e.g., patents and trademarks) are recognized when purchased (Forte et al., 2017).

In the literature, many researchers have conducted research on the factors affecting IC performance (Saleh, Rahman, \& Hassan, 2009; Al-Musalli \& Ismail, 2012; Wahid et al., 2013; Greco, Ferramosca, \& Allegrini, 2014; Makki \& Loddhi, 2014; Shahveisi, Khairollahi, \& Alipour, 2016; Supradnya, Ulupui, \& Putri, 2016; Forte et al., 2017). In summary, these studies examine the effect of corporate governance and ownership structure on IC performance.

Al-Musalli \& Ismail (2012), Wahid et al. (2013), and Makki \& Loddhi (2014) conducted research related to the effect of corporate governance on IC performance. Wahid et al. (2013) and Makki \& Loddhi (2014), prove that corporate governance positively affects IC performance. However, AlMusalli \& Ismail (2012) prove that corporate governance negatively affects IC performance.

Saleh, Rahman, \& Hassan (2009), Al-Musalli \& Ismail (2012), Greco, Ferramosca, \& Allegrini (2014), Forte et al. (2017) conducted research related to the effect of family ownership on IC performance. 
Greco, Ferramosca, \& Allegrini (2014) and Forte et al. (2017) prove that family ownership positively affects IC performance. However, Saleh, Rahman, \& Hassan (2009) and Al-Musalli \& Ismail (2012) prove that family ownership negatively affects IC performance.

Saleh, Rahman, \& Hassan (2009), Al-Musalli \& Ismail (2012), and Supradnya, Ulupui, \& Putri (2016) researched the effect of foreign ownership on IC performance. Supradnya, Ulupui, \& Putri (2016) proved that foreign ownership positively affects IC performance. However, Saleh, Rahman, \& Hassan (2009) and Al-Musalli \& Ismail (2012) prove that foreign ownership does not affect IC performance.

Saleh, Rahman, \& Hassan (2009), Al-Musalli \& Ismail (2012), and Shahveisi, Khairollahi, \& Alipour (2016), researched the effect of government ownership on IC performance. Shahveisi, Khairollahi, \& Alipour (2016) prove that government ownership negatively affects IC performance. Saleh, Rahman, \& Hassan (2009) and Al-Musalli \& Ismail (2012) prove that government ownership does not affect IC performance.

Previous studies have proved inconsistent results. Therefore, researchers are interested in examining the effect of corporate governance and ownership structures on IC performance. This research will examine the effect of corporate governance and ownership structure on IC performance in Indonesian banking with some differences from previous research. This research has differences with previous research in the following ways: (1) there is an additional variable for the implementation of digital banking in Indonesia. This is because, in the digital era like today, the banking industry relies on digital banking in attracting customers so that digital banking becomes the key to achieving competitive advantage (Mbama \& Ezepue, 2018). In addition, only a few previous research that examines digital banking; (2) the measurement of corporate governance in this research uses an index, while previous research (Al-Musalli \& Ismail, 2012; Makki \& Loddhi, 2014) measures separately as board size, number of independent commissioners, and number of audit committee meetings.

\section{HYPOTHESES DEVELOPMENT}

Over the past few years the growth of information and communication technology in the global banking industry is accelerating (Sharma et al., 2017). The banking industry implements technology to achieve competitive advantage through a larger customer base and personalized banking services for reduced operational costs (Sharma, Govindaluri, \& Al Balushi, 2015; Laukkanen, 2016). Consistent with resources-based theory, the company's resources can be a key driver in the performance and competitiveness of enterprises (Riahi-Belkaoui, 2003). Acharya, Kagan, \& Lingam (2008) researched the implementation of online banking, with a sample of bank communities in the US. The results of this research prove that the increase in online banking positively affects financial performance. Al-Smadi \& Al-Webel (2011) researched with a sample of 15 Jordanian banks during the period 2000-2010. The result proves that e-banking negatively affects bank performance. This can happen because bank customers in Jordan prefer to transact traditionally than ebanking.

Based on the perspective of resources based theory and existing research (Acharya, Kagan, \& Lingam, 2008), the researchers expect the higher the implementation of digital banking; the company will be more efficient to increase the IC performance. Therefore, this research formulates the first hypothesis as follows:

$\mathrm{H}_{1}$ : the implementation of digital banking positively affects IC performance

Shleifer \& Vishny (1997) mentioned that corporate governance is a concept based on agency theory in the hope of being a tool to convince inves- 


\section{Jurnal Keuangan dan Perbankan | BANKING}

Volume 22, Issue 4, October 2018: 715-734

tors that they will get a return on their investment. Weak corporate governance can lead to an inability to create and maintain IC (Wahid et al., 2013). This is because corporate governance has the responsibility to formulate strategic plans, engage in important decisions, monitor management and be responsible for IC investments (Keenan \& Aggestam, 2001). Wahid et al. (2013) and Makki \& Loddhi (2014) prove that corporate governance positively affects IC performance. However, Al-Musalli \& Ismail's (2012) research with a sample of 74 banks registered on the Gulf Cooperation Council (GCC) proved that corporate governance negatively affects IC performance. Corporate governance in the research of AlMusalli \& Ismail (2012) was measured by the size of the board and the presence of independent directors.

Based on agency theory and previous research (Wahid et al., 2013; Makki \& Loddhi, 2014), the researchers expect the higher the implementation of corporate governance; the IC performance can increase. Thus, this research formulates the second hypothesis as follows:

$\mathrm{H}_{2}$ : corporate governance positively affects IC performance

Arifin \& Rachmawati (2006) state that the most dominant ownership structure in Indonesia is family owned. Claessens, Djankov, \& Lang (2000) also state that families own around 67 percent of companies in Indonesia. If viewed from the agency theory, the conflict of interest between management and owners is increasing when the family ownership of the company becomes smaller. This is because company management will usually try to maximize their personal interests rather than the interests of the company (Andres, 2008). However, the presence of high family ownership can cause entrenchment effects, namely acts of abuse of power that can harm minority shareholders (Fan \& Wong, 2002). Higher family ownership makes family wealth tied to the wealth of the company so that manage- ment who is also the owner always tries to reduce all risks of losing their wealth (Pukthuanthong et al., 2013). Family ownership can cause a reduction in long-term investment, which will reduce IC performance (Saleh, Rahman, \& Hassan, 2009). Greco, Ferramosca, \& Allegrini (2014) and Forte et al. (2017) prove that family ownership positively affects IC performance. However, Saleh, Rahman, \& Hassan (2009) and Al-Musalli \& Ismail (2012) prove that family ownership negatively affects IC performance.

Based on theoretical studies and previous research (Saleh, Rahman, \& Hassan, 2009; Al-Musalli \& Ismail, 2012), the researchers expect that the higher the family ownership, the IC performance will decrease. Therefore, this research formulates the third hypothesis as follows:

$\mathrm{H}_{3}$ : family ownership negatively affects IC performance

Over the past few years, many Asian developing countries have opened the banking system to foreign competition (Gopalan \& Rajan, 2010). Further, Gopalan \& Rajan (2010) argue that the level of foreign ownership in Indonesia has increased dramatically compared to Thailand and the Philippines. Gulamhussen \& Guerreiro (2009) mentioned that with the presence of foreign ownership can improve monitoring and can influence management to be able to adopt better technology. Companies with foreign ownership change their strategy with new perspectives and ideas to improve company performance (Polovina \& Peasnell, 2015). Consistent with institutional theory, when there is an ambiguous goal or inadequate understanding of information technology, companies will imitate foreigners or are called mimetic pressure (March \& Olsen, 1976). Kamardin, Bakar, \& Ishak (2017) examine foreign ownership on Intellectual Capital Disclosure (ICD). The result proves that foreign ownership positively affects ICD. Khlif, Ahmed, \& Souissi (2017) analyzed 69 empirical studies; the result proves that foreign ownership positively affects voluntary disclosure. 
Supradnya, Ulupui, \& Putri (2016) researched with a sample of 49 companies listed on the IDX. The results prove that the foreign ownership positively affects IC performance. However, Saleh, Rahman, \& Hassan (2009) and Al-Musalli \& Ismail (2012) prove that foreign ownership does not affect IC performance. The main reason is Saleh, Rahman, \& Hassan (2009) used a sample of companies listed on the stock exchange less than ten years so that foreign ownership does not affect IC performance.

Based on theoretical studies and previous research by Supradnya, Ulupui, \& Putri (2016), Kamardin, Bakar, \& Ishak (2017), and Khlif, Ahmed, \& Souissi (2017), the researchers expect that the higher the foreign ownership, the IC performance will increase. Thus, this research formulates the fourth hypothesis as follows:

$\mathrm{H}_{4}$ : foreign ownership positively affects IC performance

Based on agency theory, if the agent and principal are different parties, it has the potential to cause agency conflict (Jensen \& Meckling, 1976). In government ownership, the government as the shareholder becomes the principal party and the management of the company becomes the agent. Companies with high government ownership cause corporate activities to be aligned with government interests (Hunardy \& Tarigan, 2017). This implies an alignment effect, which indicates that management's actions must be in line with the interests of the majority shareholders (Fan \& Wong, 2002).

Sabrina \& Muharam (2013) prove that government ownership positively affects banking financial performance. In Indonesia, banks with high government ownership will be under the supervision of the Ministry of State-Owned Enterprises and the Financial Services Authority. Therefore, banks with high government ownership can focus on increasing performance. However, Shahveisi, Khairollahi, \& Alipour (2016) prove that government ownership negatively affects IC performance. High government ownership causes the potential for political intervention so that investment decisions only aim for the short term (Saleh, Rahman, \& Hassan, 2009). In contrast, Saleh, Rahman, \& Hassan (2009) and Al-Musalli \& Ismail (2012) prove that government ownership does not affect IC performance.

Based on theoretical studies and previous research by Sabrina \& Muharam (2013), the researchers expect that the higher the government ownership, the IC performance will increase. Therefore, this study formulates the fifth hypothesis as follows: $\mathrm{H}_{5}$ : government ownership positively affects IC performance.

The ownership structure can be a controlling aspect in corporate governance mechanisms (Perrini, Rossi, \& Rovetta, 2008; Connelly et al., 2010; Saputra \& Wardhani, 2017). One way to limit opportunistic management actions in agency theory is to apply corporate governance that serves as a tool to ensure that directors and management act best for the company's interests (Watts, 2006). Azila-Gbettor et al. (2018) argue that corporate governance consists of structure and process. Furthermore, AzilaGbettor et al. (2018) explain that ownership and board are Corporate Governance Structures (CGS). CGS aims to set discipline the behavior of corporate governance actors, such as directors and executive managers. Corporate Governance Processes (CGP) refer to the interaction of governance actors based on governance structures (Sarbah \& Xiao, 2015 in Azila-Gbettor et al., 2018).

Family owners can control the company in various ways. One way is through family board members. Family board members can influence decision making by expressing opinions on board meetings (Sakawa \& Watanabel, 2018). Companies with family ownership may face problems. First, family ownership can be a source of entrenchment, which can reduce corporate value (Shleifer \& Vishny, 1997). Secondly, the increase in family ownership will cause their wealth to be tied to the wealth of the 
company so that the management who is also the owner of the company always tries to reduce the risk of losing its wealth (Pukthuanthong et al., 2013). Consequently, family ownership causes a reduction in the long-term investment that will reduce IC performance (Saleh, Rahman, \& Hassan, 2009).

In terms of foreign ownership, Tunay \& Yüksel (2017) argue that there is relevancy between corporate governance and foreign ownership. Tunay \& Yüksel (2017) explained that foreign banks could improve corporate governance in the countries which they operate. Min \& Bowman (2015) prove that an increase in foreign ownership can improve corporate governance systems. Foreign ownership can improve monitoring and may influence management to adopt better technology (Gulamhussen \& Guerreiro, 2009). Polovina \& Peasnell (2015) also argue that companies with foreign ownership can change their strategy by bringing new perspectives and ideas to improve corporate performance. Based on the explanation above, then this research formulate hypotheses as follows:

$\mathrm{H}_{6}$ : family ownership weakens the effect of corporate governance on IC performance.

$\mathrm{H}_{7}$ : foreign ownership strengthens the effect of corporate governance on IC performance

\section{METHODS}

This research is hypothesis testing research. In this research, data came from the company's annual report for the period 2012-2016 which was downloaded through www.idx.com. In addition, data were also obtained from various online sources on the internet related to the research variables. This research uses a regression method with panel data. Panel data is data that consists of time series data and cross-section (Gujarati, 2009).

The population used in this research were all banking companies listed on the Indonesia Stock Exchange from 2012-2016. This research chooses a sample using a purposive sampling technique, taking samples in accordance with the sample requirements with criteria as follows: (1) banking companies must have positive VA; (2) excluding sharia banking, because corporate governance in Islamic banking is different from conventional banking.

The total listed banking companies are 43 companies, but the sample companies are 26 companies. The total observations used in this research were 130 cases. The summary of research samples based on sampling criteria are presented in Table 1.

This research uses Microsoft Excel and Eviews 9 in the data processing process. The reasons underlying the selection of Eviews software because Eviews can choose the best test method between Pool Least Square (Common Effect), Fixed Effect and Random Effect.

This research aims to: (1) examine the effect of the implementation of digital banking (DB), corporate governance (CG), family ownership (FAMILY), foreign ownership (FOREIGN), and government ownership (GOV) on IC performance (VAIC); and (2) examine the effect of interaction between corporate governance and ownership structure on the IC performance. Control variables used were firm age (AGE), firm size (SIZE), and leverage (LEV). This research model using the model as follows:

Table 1. The Summary of Research Samples Based on Sampling Criteria

\begin{tabular}{lr}
\hline \multicolumn{1}{c}{ Description } & Total \\
\hline Banking companies are listed on the IDX & 43 \\
Companies outside the observation period (not sampling criteria) & $(11)$ \\
Banking companies that have a negative VA (not sampling criteria) & $(5)$ \\
Sharia Banking (not sampling criteria) & $(1)$ \\
The company used as the research sample & 26 \\
\hline
\end{tabular}


Digital Banking, Corporate Governance, Ownership Structure, and Intellectual Capital Performance...

Ratna Dewi Tjendani, Ari Kuncara Widagdo, \& Muthmainah Muthmainah

$\begin{aligned} \mathrm{VAIC}= & \mathrm{a}+\beta_{1} \mathrm{DB}+\beta_{2} \mathrm{CG}+\beta_{3} \text { FAMILY }+ \\ & \beta_{4} \text { FOREIGN }+\beta_{5} \mathrm{GOV}+\beta_{6} \mathrm{CG} \times \mathrm{FAMILY}+ \\ & \beta_{7} \mathrm{CG} \times \text { FOREIGN }+\beta_{8} \mathrm{AGE}+\beta_{9} \mathrm{SIZE}+ \\ & \beta_{10} \mathrm{LEV}+\varepsilon\end{aligned}$

In this research, the measurement of IC performance using VAIC (Saleh, Rahman, \& Hassan, 2009; Al-Musalli \& Ismail, 2012; El-Bannany, 2012; Greco, Ferramosca, \& Allegrini, 2014; Makki \& Loddhi, 2014; Shahveisi, Khairollahi, \& Alipour, 2016; Kamardin, Bakar, \& Ishak, 2017). VAIC represents the level of efficiency in value creation. This research uses VAIC as a measure of IC performance because the required data is available in the audited financial statements of the company so that it is more objective and verifiable (Pulic, 2000). Pulic (2004) simplifies the calculation of the total VA using the information contained in the annual report as follows:

$V A=O P+E C+D+A$

Description:

$\mathrm{OP}=$ operating profits

$\mathrm{EC}=$ total employee cost

$\mathrm{D}=$ depreciation

$\mathrm{A}=$ amortization (HCE):

Calculation of Human Capital Efficiency

$H C E=\frac{V A}{H C}$

Description:

Human Capital $(\mathrm{HC})=$ employee expenses include salaries and benefits

Calculation of Structural Capital (SC):

$S C=V A-H C$
(SCE)

$S C E=\frac{S C}{V A}$

Calculation of Capital Employed Efficiency (CEE)

$C E E=\frac{V A}{C E}$

Description:

Capital Employed (CE) = available funds (equity and net income)

Calculation of Value Added Intellectual Coeficient (VAIC ${ }^{\mathrm{TM}}$ )

$V A I C^{\mathrm{TM}}=H C E+S C E+C E E$

The implementation of digital banking in this research was measured using an index from Cisco Consulting (Bradley et al., 2014). The reason for using the index from Cisco Consulting because the index represents various digital banking channels. In addition, there is no digital banking index used in Indonesia, and it is expected the index from Cisco can represent the implementation of digital banking in Indonesia. The index consists of 21 items include dial-up experience, email contact center, online brochureware, databases, customer relation management, web-based account origination, online calculators and bill pay, click to chat \& call, data warehouse, know your customer, seamless experience, full-function smartphone apps, internal \& hybrid cloud, click-to-video, big data \& analytics, 360 customer views, digital banks, digital branches, rich cross-channel collaboration \& advice, Omnichannel analytics, market one customer-centricity, and Intercloud. The company gets a score of 1 if it has implemented the item in the index and the company will get a value of 0 if it has not used the items in the index. Then, summed of the scores and divided 
by 21 items to obtain the final score for the implementation of digital banking.

The measurement of corporate governance in this research uses an index from Hermawan (2011). This research choose the index from Hermawan (2011) because this index is more appropriate when applied in Indonesia, even many researchers have used this index in Indonesia (Muhammadi, 2016; Herusetya, 2017; Prayogo \& Agoes, 2017). This index reflects the effectiveness of the board of commissioners and audit committee which includes independence, activity, number of members, and competence - the assessment of the index divided into three categories. Good get 3 scores, fair gets 2 scores, and bad or no information gets 1 score. The score is then summed to get the final score for corporate governance.

The measurement of family ownership in this research is measured by the percentage of share ownership owned by the family (Villalonga \& Amit, 2006; Al-Musalli \& Ismail, 2012).

The measurement of foreign ownership in this research is measured by the percentage of share ownership owned by the foreign (Saleh, Rahman, \& Hassan, 2009; Kamardin, Bakar, \& Ishak, 2017).

The measurement of government ownership in this research is measured by the percentage of share ownership owned by the government (Saleh, Rahman, \& Hassan, 2009; Al-Musalli \& Ismail, 2012).

The measurement of age in this research uses the natural $\log (\ln )$ of the length of the company established (Forte et al., 2017). El-Bannany (2012) states that age is a proxy for a company's success. Usually, older companies achieve better performance than younger ones.

In this research, size will be calculated by the natural $\log (\ln )$ of total assets at the end of the year (Al-Musalli \& Ismail, 2012; El-Bannany, 2012; Greco, Ferramosca, \& Allegrini, 2014; Shahveisi, Khairollahi, \& Alipour, 2016). The facilities to larger companies can help to achieve a competitive advantage than smaller ones (El-Bannany, 2012).

The measurement of leverage using debt to equity ratio, calculated by dividing total liabilities by total equity of the company (Saleh, Rahman, \& Hassan, 2009; Kamardin, Bakar, \& Ishak, 2017). Keenan \& Aggestam (2001) argue that stakeholders increase fiduciary responsibility to monitor IC investment. Companies can be forced to manage their IC more actively.

\section{RESULTS}

Table 3 presents descriptive statistics on each variable in this research. Based on the results of descriptive statistics, the mean value of VAIC is 3.112, while the standard deviation is 0.807 . The maximum VAIC is 4.799 owned by Bank Central Asia (BBCA) in 2013. The minimum VAIC is -0.387 owned by Bank MNC International (BABP) in 2014.

The mean value of the implementation of digital banking (DB) is 0.492 , while the standard devia-

Table 2. Operational Definition Variables

\begin{tabular}{ll}
\hline \multicolumn{1}{c}{ Variables } & \multicolumn{1}{c}{ Operational Definition } \\
\hline IC Performance & Using VAIC from Pulic (2004) \\
The Implementation of Digital Banking & Using index adapted from Cisco Consulting (Bradley et al., 2014) \\
Corporate Governance & Using index from Hermawan (2011) \\
Family Ownership & Percentage of share ownership owned by the family \\
Foreign Ownership & Percentage of share ownership owned by the foreign \\
Government Ownership & Percentage of share ownership owned by the government \\
Age & Natural log (ln)of the length of the company established \\
Size & Natural log of total assets \\
Leverage & Debt to equity ratio, calculated by dividing total liabilities by total equity \\
& of the company \\
\hline
\end{tabular}


tion is 0.123 . The maximum $\mathrm{DB}$ is 0.810 owned by BBCA in 2016. The minimum DB is 0.286 owned by BABP in 2012-2015, Bank Capital Indonesia (BACA) in 2012-2016, Bank Nusantara Parahyangan (BBNP) in 2012-2014, Bank J Trust Indonesia (BCIC) in 20122014, Bank Pembangunan Daerah Banten (BEKS) in 2012-2013, Bank Victoria International (BVIC) in 2012-2015, Bank Artha Graha International (INPC) in 2012, Bank Mayapada International (MAYA) in 2012-2013, and Bank China Construction (MCOR) in 2012-2013.

The mean value of corporate governance (CG) is 78.546, while the standard deviation is 3.093 . The maximum CG is 84.000 owned by Bank Rakyat Indonesia (BBRI) in 2015-2016, Bank Jabar Banten (BJBR) in 2016, Bank Mandiri (BMRI) in 2012 and 2014, Bank Tabungan Pensiunan Nasional (BTPN) in 2016. The minimum CG is 71.000 owned by BBNP in 2016.

The mean value of the family ownership (FAMILY) is 24.061, while the standard deviation is 28.262. The maximum FAMILY is 90.900 owned by Bank Bumi Arta (BNBA). The minimum FAMILY is 0.000 owned by Bank Rakyat Indonesia Agro Niaga (AGRO), Bank Bukopin (BBKP) in 2012, Bank Negara Indonesia (BBNI), BBRI, Bank Tabungan Negara (BBTN), Bank Danamon Indonesia (BDMN), BJBR, Bank Pembangunan Daerah Jawa Timur (BJTM), BMRI, Bank CIMB Niaga (BNGA),
Maybank Indonesia (BNII), BTPN, and Bank OCBC NISP (NISP).

The mean value of foreign ownership (FOREIGN) is 35.850 , while the standard deviation is 32.981. The maximum FOREIGN is 98.383 owned by BNII in 2012. The minimum FOREIGN is 0,000 owned by AGRO in 2012, BBCA in 2012, BBKP, BNBA in 2012-2015, Bank Sinar Mas (BSIM) in 20132015, Bank Artha Graha International (INPC) in 2015, MCOR in 2012-2015, and Bank Mega (MEGA).

The mean value of government ownership (GOV) is 17.705, while the standard deviation is 28.687. The maximum GOV is 80.000 owned by BJTM in 2012-2015. The minimum GOV is 0.000 owned by BABP, BACA, BBCA in 2012-2014, BBNP, BDMN, BNBA, BNGA, BNII, BSIM, BTPN, BVIC, INPC, MAYA, MCOR, MEGA, NISP, Bank Pan Indonesia (PNBN), and Bank Woori Saudara Indonesia (SDRA).

The Chow test and The Hausman test prove that the fixed effect model is the best model that can be used in this research. Based on the results of the F test, all models have a significance of 0.000 . Because the significance level is less than 0.05 (5 percent), then all models can be used to predict the dependent variable, IC performance. Table 4 presents the results of the regression model 1 . Table 4 presents the research model in 3 parts, model $\mathrm{A}$, model B, and model C. Model A is a research model

Table 3. Descriptive Statistics

\begin{tabular}{|c|c|c|c|c|}
\hline Variables & Minimum & Maximum & Mean & Std. Deviation \\
\hline VAIC & 0.387 & 4.799 & 3.112 & 0.807 \\
\hline DB & 0.286 & 0.810 & 0.492 & 0.123 \\
\hline CG & 71.000 & 84.000 & 78.546 & 3.093 \\
\hline FAMILY & 0.000 & 90.900 & 24.061 & 28.962 \\
\hline FOREIGN & 0.000 & 98.383 & 35.850 & 32.981 \\
\hline GOV & 0.000 & 80.000 & 17.705 & 28.687 \\
\hline AGE & 2.634 & 4.796 & 3.784 & 0.484 \\
\hline SIZE & 15.063 & 20.761 & 17.850 & 1.533 \\
\hline LEV & 3.208 & 13.244 & 7.350 & 2.216 \\
\hline
\end{tabular}

Notes: DB: implementation of digital banking; CG: corporate governance; FAMILY: family ownership; FOREIGN: foreign ownership; GOV: government ownership; AGE: company age; SIZE: corporate size; LEV: leverage 
without control variables. Model B is a research model with control variables. Model $C$ is a model for moderating variables. The purpose of presenting the three models is to present the changes in each addition of variables (control and moderation).

Based on the results of regression, the significance value of DB is 0.7358 , while the coefficient value is 0.2711 . The significance value of $\mathrm{DB}$ is greater than the significance level of 5 percent. Thus, the implementation of digital banking in Indonesia has no significant effect on IC performance, which means data do not support the first hypothesis of this research.

The results of the regression prove that the CG significance value is 0.0008 , while the coefficient value is 0.0654 . The significance value of CG is smaller than the significance level of 5 percent. This means that corporate governance positively affects
IC performance. Thus, the second hypothesis of this research is supported by data.

The results of regression prove that the FAMILY significance value is 0.4995 , while the coefficient value is 0.0040 . The significance value of FAMILY is greater than the significance level of 5 percent. Thus, family ownership has no significant effect on IC performance, which means that data do not support the third hypothesis of this research.

The results of regression prove that the FOREIGN significance value is 0.8386 , while the coefficient value is -0.0009 . The significance value of FOREIGN is greater than the significance level of 5 percent. Thus, foreign ownership has no significant effect on IC performance, which means that data do not support the fourth hypothesis of this research.

The results of regression prove that the GOV significance value is 0.9944 , while the coefficient

Table 4. Model 1

\begin{tabular}{|c|c|c|c|c|c|c|c|}
\hline \multirow{3}{*}{ Variables } & \multirow{3}{*}{$\begin{array}{l}\text { Exp. } \\
\text { Sign }\end{array}$} & \multicolumn{6}{|c|}{ Fixed Effect Model } \\
\hline & & \multicolumn{2}{|c|}{$\mathbf{A}$} & \multicolumn{2}{|c|}{ B } & \multicolumn{2}{|c|}{ C } \\
\hline & & Coeff & Prob & Coeff & Prob & Coeff & Prob \\
\hline \multicolumn{8}{|l|}{ Independent } \\
\hline DB & + & -2.0183 & 0.0059 & -0.1390 & 0.8653 & -0.0664 & 0.9365 \\
\hline CG & + & 0.0636 & 0.0036 & 0.0497 & 0.0140 & -0.0083 & 0.8354 \\
\hline FAMILY & - & 0.0002 & 0.9691 & 0.0032 & 0.6002 & 0.0820 & 0.1636 \\
\hline FOREIGN & + & 0.0005 & 0.9079 & -0.0018 & 0.6968 & -0.0673 & 0.1666 \\
\hline GOV & + & 0.0057 & 0.8655 & -0.0028 & 0.9282 & -0.0055 & 0.8603 \\
\hline \multicolumn{8}{|l|}{ Control } \\
\hline AGE & & & & -7.0099 & 0.0000 & -7.4794 & 0.0000 \\
\hline SIZE & & & & 0.5247 & 0.0462 & 0.5887 & 0.0424 \\
\hline LEV & & & & -0.0263 & 0.3479 & -0.0277 & 0.3200 \\
\hline \multicolumn{8}{|l|}{ Moderating } \\
\hline CG*FAMILY & Weaken & & & & & 0.0011 & 0.1438 \\
\hline CG*FOREIGN & Strengthen & & & & & 0.0008 & 0.1730 \\
\hline R-squared & & & 0.804302 & & 0463 & & 0.845100 \\
\hline Adjusted $R^{2}$ & & & 0.745000 & & 5622 & & 0.787425 \\
\hline F-statistic & & & 13.56274 & & 2547 & & 14.65267 \\
\hline Prob(F-statistic) & & & 0.000000 & & 0000 & & 0.000000 \\
\hline
\end{tabular}

Notes: DB: implementation of digital banking; CG: corporate governance; FAMILY: family ownership; FOREIGN: foreign ownership; GOV: government ownership; AGE: company age; SIZE: corporate size; LEV: leverage 
value is -0.0002 . The significance value of GOV is greater than the significance level of 5 percent. Thus, government ownership has no significant effect on IC performance, which means that data do not support the fifth hypothesis of this research.

The results of regression prove that the CG*FAMILY significance value is 0.7814 , while the coefficient value is 0.0002 . The significance value of $\mathrm{CG}^{*} \mathrm{FAMILY}$ is greater than the significance level of 5 percent. Thus, the interaction between corporate governance and family ownership has no significant effect on IC performance, which means that data do not support the sixth hypothesis of this research.

The results of regression prove that the $\mathrm{CG}^{*}$ FOREIGN significance value is 0.1680 , while the coefficient value is 0.0008 . The significance value of $\mathrm{CG}^{*} \mathrm{FOREIGN}$ is greater than the significance level of 5 percent. Thus, the interaction between corporate governance and foreign ownership has no significant effect on IC performance, which means that data do not support the seventh hypothesis of this research.

\section{DISCUSSION}

\section{The Implementation of Digital Banking on IC Performance}

The regression results in model A (without control variables) prove that the implementation of digital banking negatively affects IC performance. However, the regression results in model B (with control variables) prove that the implementation of digital banking does not affect IC performance. Researchers suspect that the difference in regression results is due to the presence of control variables in model B. Especially because age and size have a significant effect on IC performance. Thus, the control variable plays an important role in influencing IC performance.

The regression results in model $\mathrm{B}$ (the main model for the implementation of the digital bank- ing in this research) prove that the implementation of digital banking does not affect IC performance, so data do not support the first hypothesis. The results of this research not consistent with Acharya, Kagan, \& Lingam (2008) which proves that the implementation of online banking positively affects US banking financial performance. The results of this research is also inconsistent with Al-Smadi \& AlWebel (2011) which proves that e-banking negatively affects Jordanian banking performance.

The results of this research different from existing research because the implementation of digital banking in Indonesia is not optimal (the average of the implementation of digital banking in Indonesia during 2012-2016 is 0.492 or equivalent with digital banking 2.0) and still in the process of developing. Figure 1 presents the average of the implementation of digital banking in Indonesia from 2012-2016.

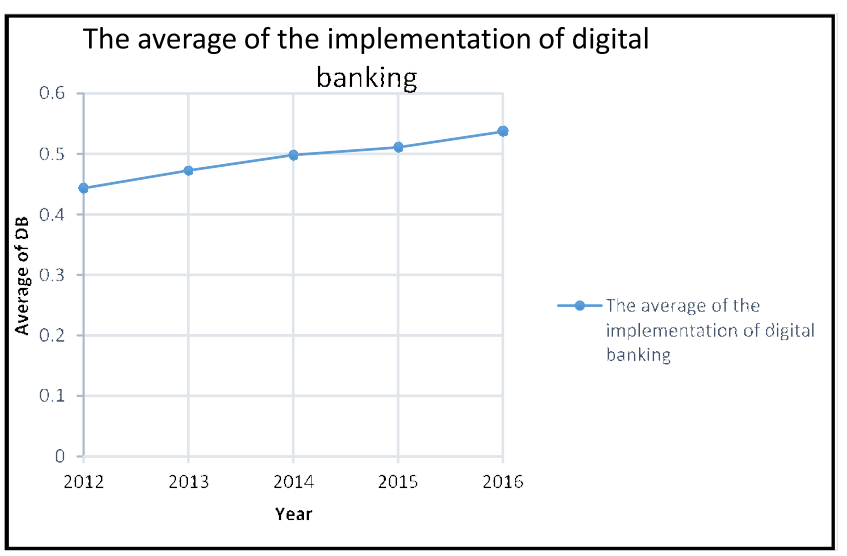

Figure 1. The Average of the Implementation of Digital Banking

Thus, researchers suspect that the implementation of digital banking in Indonesia still requires time to influence IC performance positively. Digital banking is a long journey, so it takes time to adjust with digital strategies, it takes time to overcome digital distractions (such as unstable internet connections) and takes time to improve bank features to suit the needs of customers (Deloitte tax \& consulting, 2017). Based on these allegations, research- 
ers argue that research on the implementation of digital banking would be better if using a different year with the dependent variable (year +1 or +2 from the year of the dependent variable). This is because the implementation variable takes time to prove its positive effects.

\section{Corporate Governance on IC Performance}

The regression results in model B prove that corporate governance positively affects IC performance, so data support the second hypothesis of this research. The results of this research not consistent with the research of Al-Musalli \& Ismail (2012) which proves that corporate governance negatively affects IC performance. However, the results of this research consistent with Wahid et al. (2013) and Makki \& Loddhi (2014), which proves that corporate governance positively affects IC performance.

This implies that corporate governance in the banking industry plays an important role in improving IC performance. The important role of corporate governance in the banking industry is supported by the existence of the Financial Services Authority, an independent institution whose job was to regulate, supervise, inspect and investigate banking business activities. The existence of the Financial Services Authority can minimize the occurrence of irregularities in corporate governance practices.

\section{Family Ownership on IC Performance}

The regression results in model B prove that family ownership does not affect IC performance so data do not support the third hypothesis. The results of this research not consistent with Greco, Ferramosca, \& Allegrini (2014) and Forte et al. (2017) prove that family ownership positively affects IC performance. The results of this research also inconsistent with Saleh, Rahman, \& Hassan (2009) and Al-Musalli \& Ismail (2012) which prove that family ownership negatively affects IC performance.
The results of this research prove different from existing research. The researchers suspect this because the average of family ownership in Indonesia during 2012-2016 was 24.06. This means that the average of family ownership does not reach a quarter of total banking ownership in Indonesia. This implies that banking companies listed on the Indonesia Stock Exchange, on average, comply with the rules on the maximum shareholding limits for each category of shareholders. This regulation is contained in Peraturan Bank Indonesia number 14/8/ PBI/2012 and Peraturan Otoritas Jasa Keuangan number 56/POJK. 03/2016.

\section{Foreign Ownership on IC Performance}

The regression results in model B prove that foreign ownership does not affect IC performance, so data do not support the fourth hypothesis. The results of this research not consistent with Supradnya, Ulupui, \& Putri (2016), Kamardin, Bakar, \& Ishak, (2017), and Khlif, Ahmed, \& Souissi (2017), which proves the positive influence of foreign ownership. However, this research consistent with Saleh, Rahman, \& Hassan (2009) and Al-Musalli \& Ismail (2012) which prove that foreign ownership does not affect IC performance.

This is because the average foreign shareholders of the Indonesian banking sector come from Asia, so the transfer of knowledge and technology is not significant in Indonesia, which also includes the Asian region. In addition, the possibility of foreign investors prefers to maintain short-term relationships that focus on profit rather than long-term relationships (Al-Musalli \& Ismail, 2012).

\section{Government Ownership on IC Performance}

The regression results in model B prove that government ownership does not affect IC performance, so data do not support the fifth hypothesis. The results of this research not consistent with Sabrina \& Muharam (2013) which proves the exist- 
ence of a positive influence from government ownership. The results of this research is also inconsistent with Shahveisi, Khairollahi, \& Alipour (2016) which proves that government ownership negatively affects IC performance. However, the results of this research consistent with Saleh, Rahman, \& Hassan (2009) and Al-Musalli \& Ismail (2012) which prove that government ownership does not affect IC performance.

This can happen one of them because not all banks have a percentage of government ownership. This research has 26 banking samples, but only eight banks have a percentage of government ownership. Another reason, companies with government ownership also have other goals such as social and political rather than maximizing profits (Shen \& Lin, 2009).

\section{The Interaction between Corporate Governance and Ownership Structure on IC Performance}

The regression results in model $\mathrm{C}$ prove that the interaction between corporate governance and family ownership does not affect IC performance, so data do not support the sixth hypothesis. The researchers suspect that this is because the fit and proper test rules for board members caused only competent people to be placed in that position. This regulation is contained in the Financial Services Authority Regulation number 55/POJK.03/2016 about implementation of corporate governance for commercial banks. Therefore, family owners do not place their representatives on board members. The results of this research are consistent with Muawanah (2014), who argues that regulation and supervision eliminate family influence in the governance process. This implies that regulation and supervision are urgent for companies with family ownership to encourage practice towards good governance (Muawanah, 2014).

The regression results in model $\mathrm{C}$ also prove that the interaction between corporate governance and foreign ownership does not affect IC performance so data do not support the seventh hypothesis. Unfortunately, researchers have not found publications or literature about the interaction of corporate governance and foreign ownership. However, the researchers suspect that the non-influential interaction between corporate governance and foreign ownership has the same reason as the noninfluential interaction between corporate governance and family ownership. The researchers suspect that this is because the fit and proper test rules for board members caused only competent people to be placed in that position. This regulation is contained in the Financial Services Authority Regulation number 55/ POJK.03/2016 about implementation of corporate governance for commercial banks. Therefore, foreign owners do not place their representatives on board members.

\section{Control Variables (Age, Size, Leverage) on IC Performance}

In the case of control variables, the regression results prove that the age of the company negatively affects IC performance. Loderer, Stulz, \& Waelchli (2016) argue that young companies invest more in research and development.

Regression results prove that firm size positively affects IC performance. El-Bannany (2012) argues that the facilities available to large companies can help companies to achieve competitive advantage.

The regression results prove that leverage does not affect IC performance. Researchers suspect this can occur because of the use of leverage inappropriate in the banking environment. Measurement of leverage in this research is total bank liabilities divided by total equity. Third-Party funds that a measure of bank success also included in the total liability component. As a result, a high leverage ratio cannot indicate bank difficulties. 


\section{Jurnal Keuangan dan Perbankan | BANKING}

Volume 22, Issue 4, October 2018: 715-734

\section{Robustness Test}

Robustness test is used to ensure the strength of the findings in the main model. The study was repeated using different measurements of digital banking and ownership structures. In the first model, researchers measured digital banking implementation in Indonesia to stage 4.0. Because the average of the implementation of digital banking in Indonesia is 0.492 (equivalent to digital banking 2.0), the second model is repeated by measuring digital banking implementation until stage 2.0. Table 5 presents the results of the second model robustness test.

The results in model $2 \mathrm{~B}$ prove consistent with model 1B. The result proves that corporate governance positively affects IC performance. In contrast, digital banking implementation, family ownership, foreign ownership, and government ownership do not affect IC performance. This indicates that the measurement of digital banking up to stage 2.0 or up to stage 4.0 consistently proves that the implementation of digital banking has no effects on IC performance.
Furthermore, this research was repeated using different ownership structure measurements. In the first model, the measurement of family and foreign ownership uses the percentage of family and foreign shareholdings. In the third model, the measurement of family and foreign ownership uses the nominal method. The company gets a score of 1 if there is a family member or foreign party on the board of commissioners. Instead, the company gets a value of 0 if there is no family member or foreign party on the board of commissioners. Table 6 presents the results of the third model robustness test.

The results in model 3B prove consistent with model $1 \mathrm{~B}$. The results in model $3 \mathrm{~B}$ prove that corporate governance positively affects IC performance. The implementation of digital banking, family ownership, foreign ownership, and government ownership do not affect IC performance. This indicates that the measurement of ownership structure using the percentage of ownership or using the existence of the board consistently proves that family ownership and foreign ownership do not affect IC performance.

Table 5. Model 2

\begin{tabular}{|c|c|c|c|c|c|c|c|}
\hline \multirow{3}{*}{ Variables } & \multirow{3}{*}{$\begin{array}{l}\text { Exp. } \\
\text { Sign }\end{array}$} & \multicolumn{6}{|c|}{ Fixed Effect Model } \\
\hline & & \multicolumn{2}{|c|}{ A } & \multicolumn{2}{|c|}{ B } & \multicolumn{2}{|c|}{$\mathrm{C}$} \\
\hline & & Coeff. & Prob. & Coeff. & Prob. & Coeff. & Prob. \\
\hline \multicolumn{8}{|l|}{ Independent } \\
\hline DB & + & -1.0112 & 0.1517 & -0.1958 & 0.8441 & -0.2635 & 0.8021 \\
\hline CG & + & 0.0736 & 0.0012 & 0.0534 & 0.0163 & 0.0331 & 0.4591 \\
\hline FAMILY & - & -0.0011 & 0.8434 & -0.0001 & 0.9856 & -0.0449 & 0.4914 \\
\hline FOREIGN & + & -0.0005 & 0.9024 & 0.0013 & 0.7982 & -0.0058 & 0.9150 \\
\hline GOV & + & 0.0042 & 0.5286 & -0.0067 & 0.8456 & -0.0072 & 0.8352 \\
\hline \multicolumn{8}{|l|}{ Control } \\
\hline AGE & & & & -5.8867 & 0.0026 & -6.1512 & 0.0023 \\
\hline SIZE & & & & 0.1467 & 0.6284 & 0.2101 & 0.5101 \\
\hline LEV & & & & 0.0036 & 0.9047 & 0.0027 & 0.9297 \\
\hline \multicolumn{8}{|l|}{ Moderating } \\
\hline CG*FAMILY & Weaken & & & & & 0.0005 & 0.4914 \\
\hline CG*FOREIGN & Strengthen & & & & & 0.0009 & 0.8897 \\
\hline R-squared & & & 0.112718 & & 0.820854 & & 0.821822 \\
\hline Adjusted $\mathrm{R}^{2}$ & & & 0.076941 & & 0.759272 & & 0.755479 \\
\hline F-statistic & & & 3.150532 & & 13.32956 & & 12.38751 \\
\hline Prob(F-statistic) & & & 0.010336 & & 0.000000 & & 0.000000 \\
\hline
\end{tabular}




\section{CONCLUSION AND SUGGESTIONS}

\section{Conclusion}

The results of this research prove that the implementation of digital banking does not affect IC performance in the same year. Researchers suspect that the implementation of digital banking still requires time to have a positive effect on IC performance. The results of this research prove that corporate governance positively affects IC performance. This implies that corporate governance in Indonesian banking has proven to play an important role in improving IC performance. The results of statistical tests prove that family ownership and foreign ownership do not affect IC performance. Strict regulations cause family and foreign shareholders in Indonesia do not place their representatives in the company. This is also the cause of the non-influence of the interaction between corporate governance and ownership structure on IC performance. The results of this research prove that government ownership does not affect IC performance. This can happen one of them because companies with government ownership also have other goals such as social and political rather than maximizing profits.

\section{Suggestions}

This research has several limitations that must be considered in interpreting the results of this research. The limitations of this research are as follows: (1) this research uses the VAIC method to measure IC performance. The data needed comes from the company's financial statements without

Table 6. Model 3

\begin{tabular}{|c|c|c|c|c|c|c|c|}
\hline \multirow{3}{*}{ Variables } & \multirow{3}{*}{$\begin{array}{l}\text { Exp. } \\
\text { Sign }\end{array}$} & \multicolumn{6}{|c|}{ Fixed Effect Model } \\
\hline & & \multicolumn{2}{|c|}{ A } & \multicolumn{2}{|c|}{ B } & \multicolumn{2}{|c|}{$\mathrm{C}$} \\
\hline & & Coeff. & Prob. & Coeff. & Prob. & Coeff. & Prob. \\
\hline \multicolumn{8}{|l|}{ Independent } \\
\hline DB & + & -2.0153 & 0.0050 & -0.2839 & 0.7295 & -0.1355 & 0.8721 \\
\hline CG & + & 0.0643 & 0.0024 & 0.0515 & 0.0095 & 0.0507 & 0.0341 \\
\hline FAMILY & - & -0.2644 & 0.1732 & -0.2461 & 0.1736 & 3.3023 & 0.4326 \\
\hline FOREIGN & + & 0.3081 & 0.2442 & 0.1141 & 0.6538 & -1.9705 & 0.5784 \\
\hline GOV & + & 0.0058 & 0.8627 & -0.0033 & 0.9136 & -0.0041 & 0.8959 \\
\hline \multicolumn{8}{|l|}{ Control } \\
\hline AGE & & & & -6.1534 & 0.0001 & -6.0952 & 0.0002 \\
\hline SIZE & & & & 0.4236 & 0.0123 & 0.3357 & 0.2312 \\
\hline LEV & & & & -0.0159 & 0.5323 & -0.0225 & 0.3940 \\
\hline \multicolumn{8}{|l|}{ Moderating } \\
\hline CG*FAMILY & Weaken & & & & & -0.0459 & 0.3983 \\
\hline CG*FOREIGN & Strengthen & & & & & 0.0270 & 0.5541 \\
\hline R-squared & & & 0.810638 & & 0.841693 & & 0.843547 \\
\hline Adjusted $\mathrm{R}^{2}$ & & & 0.753256 & & 0.787275 & & 0.785293 \\
\hline F-statistic & & & 14.12695 & & 15.46717 & & 14.48053 \\
\hline Prob(F-statistic) & & & 0.000000 & & 0.000000 & & 0.000000 \\
\hline
\end{tabular}


considering non-monetary aspects; (2) the way to fill in the indexes in this research conducted by researchers alone so it cannot be separated from subjectivity; (3) measurement of family ownership and foreign ownership in this research only uses the percentage of share ownership and the existence of the board without considering aspects of cultural background or purpose of ownership; and(4) the leverage variable as a control variable calculated by dividing total liabilities and total equity. The total liability component includes third-party funds that measure the success rate of the bank.

Based on these limitations, suggestions that can be given for further research as follows: (1) future research can use methods other than VAIC so that it can be used as a comparison with the VAIC method. For example, non-monetary methods such as Vital Sign Scorecard (VanderKaay, 2000) or the Ernst \& Young Model (Barsky \& Marchant, 2000); (2) the way to fill the index in the next research is done by confirming more than one person. Even if possible can involve experts in filling in these indexes; (3) further research can measure the ownership structure other than the percentage of share ownership and the existence of the board, for example by considering aspects of cultural background and purpose of ownership; and (4) control variables in subsequent research in the banking industry can use variables other than leverage - for example, the variable Loan Deposit Ratio (LDR) which shows the amount of credit given with funds received by the bank.

\section{REFERENCES}

Abhayawansa, S., \& Guthrie, J. (2016). Does intellectual capital disclosure in analysts' reports vary by firm characteristics/ ? Advances in Accounting, 35, 26-38. https:/ /doi.org/10.1016/j.adiac. 2016.04.002

Acharya, R. N., Kagan, A., \& Lingam, R. S. (2008). Online banking applications and community bank performance. International Journal of Bank Marketing, 26(6), 418-439. https://doi.org/ 10.1108/02652320810902442

Alhassan, A. L., \& Asare, N. (2016). Intellectual capital and bank productivity in emerging markets: evidence from Ghana. Management Decision, 54(3), 589-609. https://doi.org/ 10.1108/MD-01-2015-0025

Al-Musalli, M. A. K., \& Ismail, K. N. I. K. (2012). Corporate governance, bank-specific characteristics, banking industry characteristics, and intellectual capital performance of banks in Arab Gulf Cooperation Council (GCC) countries. Asian Academy of Management Journal of Accounting and Finance, 8(1), 115135.

Al-Musali, M. A., \& Ismail, K. N. I. K. (2016). Cross-country comparison of intellectual capital performance and its impact on financial performance of commercial banks in GCC countries. International Journal of Islamic and Middle Eastern Finance and Management, 9(4), 512-531.

Al-Smadi, M. O., \& Al-Wabel, S. A. (2011). The impact of e-banking on the performance of Jordanian banks. Journal of Internet Banking and Commerce, 16(2).

Andres, C. (2008). Large shareholders and firm performance - An empirical examination of founding-family ownership. Journal of Corporate Finance, 14(4), 431445. https://doi.org/10.1016/ j.jcorp
Arifin, Z., \& Rachmawati, N. (2006). Pengaruh corporate governance terhadap efektifitas mekanisme pengurang masalah agensi. Jurnal Siasat Bisnis, 11(3), 237-247. http://jurnal. uii.ac.id/index.php/JSB/article/view/236

Azila-Gbettor, E. M., Honyenuga, B. Q., Berent-Braun, M. M., \& Kil, A. (2018). Structural aspects of corporate governance and family firm performance: A systematic review governance. Journal of Family Business Management, 8(3), 306-330. https://doi.org/ 10.1108/JFBM-12-2017-0045

Barsky, N. P., \& Marchant, G. (2000). The most valuable resource Measuring and managing intellectual capital. Strategic Finance, 81(8), 58-62.

Bradley, J., Loucks, J., Jameson, P., O'Connell, K., \& Barbier, J. (2014). Reimagining the digital bank. Cisco and/or its affiliates. 
Digital Banking, Corporate Governance, Ownership Structure, and Intellectual Capital Performance...

Ratna Dewi Tjendani, Ari Kuncara Widagdo, \& Muthmainah Muthmainah

Retrieved from: https:// www.cisco.com/c/dam/en/ us/solutions/collateral/executive-perspectives/Internetof-Everything-executivesummary.pdf.

Chartered Institute of Management Accountants. (2000). CIMA Annual Report. Kuala Lumpur.

Claessens, S., Djankov, S., \& Lang, L. H. P. (2000). The separation of ownership and control in East Asian corporations. Journal of Financial Economics, 58(1-2), 81112. https://doi.org/10.1016/ S0304-405X(00)00067-2

Connelly, B. L., Hoskisson, R. E., Tihanyi, L., \& Certo, S. T. (2010). Ownership as a form of corporate governance. Journal of Management Studies, 47(8), 15611589. https://doi.org/10.1111/ j. 1467-6486.2010.00929.x

Daryaee, A., Pakdel, A., Easapour, K., \& Khalaflu, M. M. (2011). Intellectual capital, corporate value, and corporate governance (evidence from Tehran Stock Exchange (TSE)). Australian Journal of Basic and Applied Sciences, 5(12), 821-826.

Deloitte Tax \& Consulting. (2017). Digital banking benchmarkimproving the digital performance. Deloitte Digital, 4-28. Retrieved from: https:// www2.deloitte.com/content/ dam/Deloitte/lu/Documents / financial-services/ Banking/lu-digital-bankingbenchmark.pdf.

Dzenopoljac, V., Yaacoub, C., Elkanj, N. \& Bontis, N. (2017). Impact of intellectual capital on corporate performance: Evidence from the Arab region. Journal of Intellectual Capital. 18(4), 884-
903. https://doi.org/10.1108/ JIC-01-2017-0014

El Bannany, M. (2012). Global financial crisis and the intellectual capital performance of UAE banks. Journal of Human Resource Costing $\mathcal{E}$ Accounting, 16(1), 20-36. https://doi.org/ $10.1108 / 14013381211272626$

Fan, J. P. H., \& Wong, T. J. (2002). Corporate ownership structure and the informativeness of accounting earnings. Journal of Accounting \& Economies, 33(3), 401-425. https://doi.org/ 10.1016/S0165-4101(02) 00047-2

Forte, W., Tucker, J., Matonti, G., \& Nicolò, G. (2017). Measuring the intellectual capital of Italian listed companies. Journal of Intellectual Capital, 18(4), 710732. https://doi.org/10.1108/ JIC-08-2016-0083

Gopalan, S., \& Rajan, R. (2010). Financial sector de-regulation in emerging Asia: Focus on foreign bank entry. MPRA Paper. University Library of Munich.

Greco, G., Ferramosca, S., \& Allegrini, M. (2014). Exploring intellectual capital in family firms. An empirical investigation. International Journal of Learning and Intellectual Capital, 11(2), 91-106. https://doi.org/10.1504/ IJLIC.2014.060802

Gujarati, D. N. (2009). Basic Econometric. New York: McGraw Hill.

Gulamhussen, M. A., \& Guerreiro, L. (2009). The influence of foreign equity and board membership on corporate strategy and internal cost management in Portuguese banks. Management Accounting Research, 20(1), 6-17. https:// doi.org/10.1016/ j.mar.2008.10.006

Hamdan, A. (2018). Intellectual capital and firm performance: Differentiating between accounting-based and market-based performance. International Journal of Islamic and Middle Eastern Finance and Management, 11(1), 139-151. https://doi.org/ 10.1108/IMEFM-02-2017-0053

Hermawan, A. A. (2011). The influence of effective board of commissioners and audit committee on the informativeness of earnings: Evidence from Indonesian listed firms. Asia Pacific Journal of Accounting and Finance, 2(1), 1-34. Retrieved from: http://apjaf.ui.ac.id/index. php/apjaf/article/view/17

Herusetya, A. (2017). Earnings benchmarks and timeliness of audit reports: Corporate governance mechanism as moderating variable. Parhyangan International 3rd Accounting and Business Conference, 627-640.

Hunardy, N., \& Tarigan, J. (2015). Pengaruh kepemilikan pemerintah terhadap kinerja keuangan melalui dewan komisaris independen sebagai variabel intervening. Business Accounting Review, 5(2), 601612.

Jensen, M., \& Meckling, W. (1976). Theory of the firm: Managerial behavior, agency costs, and ownership structure. Journal of Financial Economics, 3(4), 305360. https://doi.org/10.1016/ 0304-405X(76)90026-X

Kamardin, H., Bakar, R. A., \& Ishak, R. (2017). Intellectual capital disclosure: The effect of family and non-executive directors on 
board. Advanced Science Letters, 23(4), 3102-3106. https:// doi.org/10.1166/asl.2017. 7665

Keenan, J., \& Aggestam, M. (2001). Corporate governance and intellectual capital: Some conceptualisations. Journal of Corporate Governance: An International Review, 9(4), 259-275. https:// doi.org/10.1111/14678683.00254

Kehelwalatenna, S. (2016). Intellectual capital performance during financial crises. Measuring Business Excellence, 20(3), 55-78. https://doi.org/10.1108/ MBE-08-2015-0043

Khairiyansyah K., \& Vebtasvili V. (2018). Relationship between intellectual capital with profitability and productivity in Indonesian banking industry. Jurnal Keuangan dan Perbankan, 22(1), 127-136. https:/ / doi. org/10.26905/jkdp.v22i1.1577

Khlif, H., Ahmed, K., \& Souissi, M. (2017). Ownership structure and voluntary disclosure: A synthesis of empirical studies. Australian Journal of Management, 42(3), 376-403. https:/ / doi.org/10.1177/031289621 6641475

Laukkanen, T. (2016). Consumer adoption versus rejection decisions in seemingly similar service innovations: The case of the internet and mobile banking. Journal of Business Research, 69(7), 2432-2439. https:// doi.org/10.1016/j.jbusres. 2016.01.013

Loderer, C., Stulz, R., \& Waelchli, U. (2016). Firm rigidities and the decline in growth opportunities firm rigidities and the decline in growth opportunities. Man- agement Science, 63(9), 27733145. https://doi.org/10.1287/ mnsc. 2016.2478

Makki, M. A., \& Lodhi, S. A. (2014). Impact of corporate governance on intellectual capital efficiency and financial performance. $\mathrm{Pa}$ kistan Journal of Commerce and Social Sciences, 8(2), 305-330.

March, J. G., \& Olsen, J. P. (1976). Ambiguity and Choice in Organizations. Norway:Universitetsforlaget.

Marr, B., \& Moustaghfir, K. (2005) Defining intellectual capital: A three dimensional approach. Management Decision, 43(9), 1114-1128. https://doi.org/ $10.1108 / 00251740510626227$

Mbama, C. I., \& Ezepue, P. O. (2018). Digital banking, customer experience, and bank financial performance: UK customers' perceptions. International Journal of Bank Marketing, 36(2), 230-255. https://doi.org/ 10.1108/IJBM-11-2016-0181

Min, B. S., \& Bowman, R. G. (2015). Corporate governance, regulation, and foreign equity ownership/ : Lessons from Korea. Economic Modelling, 47, 145155. https://doi.org/10.1016/ j.econmod.2015.02.030

Mondal, A., \& Ghosh, S. K. (2012). Intellectual capital and financial performance of Indian banks. Journal of Intellectual Capital, 13(4), 515-530. https://doi. org / $10.1108 / 1469193$ 1211276115

Muawanah, U. (2014). Corporate governance dan kepemilikan keluarga. Jurnal Akuntansi Multiparadigma, 5(2), 299-313. http:/ /dx.doi.org/10.18202/ jamal.2014.08.5024
Muhammadi, A. H. (2016). Three essays on political connections, financial reporting, and auditing-evidence from Indonesian listed companies. Unpublished doctoral dissertation. Massey University New Zealand.

Osinski, M., Selig, P. M., Matos, F., \& Roman, D. J. (2017). Methods of evaluation of intangible assets and intellectual capital. Journal of Intellectual Capital, 18(3), 470485. https://doi.org/10.1108/ JIC-12-2016-0138

Ozkan, N., Cakan, S., \& Kayacan, M. (2017). Intellectual capital and financial performance: A study of the Turkish banking sector. Borsa Istanbul Review, 17(3), 190-198. https://doi.org/ 10.1016/j.bir.2016.03.001

Peraturan Bank Indonesia number 14/ 8/PBI/2012. (2012). Kepemilikan Saham Bank Umum.

Peraturan Otoritas Jasa Keuangan number 55/POJK.03/2016. (2016). Penerapan Tata Kelola Bagi Bank Umum.

Peraturan Otoritas Jasa Keuangan number 56/POJK. 03/2016. (2016). Kepemilikan Saham Bank Umum.

Perrini, F., Rossi, G., \& Rovetta, B. (2008). Does ownership structure affect performance? Evidence from the Italian Market, Corporate Governance: An International Review, 16(4), 312-325. https://doi.org/10.1111/ j.1467-8683.2008.00695.x

Pukthuanthong, K., Walker, T. J., Thiengtham, D. N., \& Du, H. (2013). Does family ownership create or destroy value? Evidence from Canada. International Journal of Managerial Finance, 9(1), 13-48. https:// 


\section{Digital Banking, Corporate Governance, Ownership Structure, and Intellectual Capital Performance...}

Ratna Dewi Tjendani, Ari Kuncara Widagdo, \& Muthmainah Muthmainah

doi.org/10.1108/17439131 311298511

Polovina, N., \& Peasnell, K. (2015). The effect of foreign management and board membership on the performance of foreign acquired Turkish banks. International Journal of Managerial Finance, 11(3), 359-387. https:/ /doi.org/10.1108/09574090 910954864

Prayogo, B., \& Agoes, S. (2017). Role of audit regulation on the effect of corporate governance and audit quality on earnings management. OIDA International Journal of Sustainable Development, 10(10), 53-66.

Pulic, A. (2000). VAIC ${ }^{\mathrm{TM}}$ - An accounting tool for IC management. International Journal Technology Management, 20(5), 702-714. https://doi.org/10.1504/ IJTM.2000.002891

Pulic, A. (2004). Intellectual capitaldoes it create or destroy value? Measuring Business Excellence, 8(1), 62-68. https://doi.org/ $10.1108 / 13683040410524757$

Riahi Belkaoui, A. (2003). Intellectual capital and firm performance of US multinational firms. Journal of Intellectual Capital, 4(2), 215226. https://doi.org/10.1108/ 14691930310472839

Rochmadhona, B. N., Suganda, T. R., \& Cahyadi, S. (2018). The competitive advantage between intellectual capital and financial performance of banking sector in ASEAN. Jurnal Keuangan dan Perbankan, 22(2), 321-334. https://doi.org/10.26905/ jkdp.v22i2.2060

Sabrina, F. N., \& Muharam, H. (2015). Analisis pengaruh kepemi likan pemerintah, kepemilikan asing, risiko likuiditas dan risiko kredit terhadap kinerja keuangan bank. Diponegoro Journal of Management, 4(1), 113. Retrieved from: https:// ejournal3.undip.ac.id/ index.php/djom/article/ view/13026

Sakawa, H., \& Watanabel, N. (2018). Family control and ownership monitoring in Stakeholder-oriented corporate governance. Management Decision. https:/ / doi.org/10.1108/MD-04-20180480

Saleh, N. M., Rahman, M. R. C. A., \& Hassan, M. S. (2009). Ownership structure and intellectual capital performance in Malaysia. Asian Academy of Management Journal of Accounting and Finance, 5(1), 1-29.

Saputra, A. A. D., \& Wardhani, R. (2017). Pengaruh efektivitas dewan komisaris, komite audit, dan kepemilikan institusional terhadap efisiensi investasi. Jurnal Akuntansi \& Auditing Indonesia, 21(1), 24-36. https://doi.org/10.20885/ jaai.vol21.iss1.art3

Schiavone, F., Meles, A., Verdoliva, V., \& Giudice, M. Del. (2014). Does location in a science park really matter for firms'intellectual capital performance? Journal of Intellectual Capital, 15(4), 497515. https://doi.org/10.1108/ JIC-07-2014-0082

Shahveisi, F., Khairollahi, F., \& Alipour, M. (2016). Does ownership structure matter for corporate intellectual capital performance/? An empirical test in the Iranian context. Eurasian Business Review. https:// doi.org/10.1007/s40821-0160050-8
Sharma, S. K., Govindaluri, S. M., \& Al Balushi, S. M. (2015). Predicting determinants of internet banking adoption. Management Research Review, 38(7), 750-766. https://doi.org/10.1108/ MRR-06-2014-0139

Sharma, S. K., Govindaluri, S. M., AlMuharrami, S., \& Tarhini, A. (2017). A multi-analytical model for mobile banking adoption: A developing country perspective. Review of International Business and Strategy, 27(1), 133-148. https://doi.org/ 10.1108/RIBS-11-2016-0074

Shleifer, A., \& Vishny, R. W. (1997). A survey of corporate governance. The Journal of Finance, 52(2), 737-783. https:// doi.org/10.1111/j.15406261.1997.tb04820.x

Shen, W., \& Lin, C. (2009). Firm profitability, state ownership, and top management turnover at the listed firms in China: A behavioral perspective. Corporate Governance: $6 t 5 A n$ International Review, 17(4), 443-456. https:/ /doi.org/10.1111/j.14678683.2009.00725.x

Supradnya, I. N. T., Ulupui, I. G. K. A., \& Putri, I. G. A. M. A.. (2016). Pengaruh jenis industri, kepemilikan manajerial, kepemilikan institusional, dan kepemilikan asing terhadap kinerja modal intelektual. Simposium Nasional Akuntansi XIX Lampung, 1-20.

Tiwari, R., \& Vidyarthi, H. (2018). Intellectual capital and corporate performance: A case of Indian banks. Journal of Accounting in Emerging Economies, 8(1), 84105. https://doi.org/10.1108/ JAEE-07-2016-0067 
Jurnal Keuangan dan Perbankan | BANKING

Volume 22, Issue 4, October 2018: 715-734

Tunay, K. B., \& Yüksel, S. (2017). The relationship between corporate governance and foreign ownership of the banks in developing countries. Contaduría $Y$ Administración, 62(5), 16271642. https://doi.org/10.1016/ j.cya.2017.05.007

Usoff, C. A., Thibodeau, J. C., \& Burnaby, P. (2002). The importance of intellectual capital and its effect on performance measurement systems. Managerial Auditing Journal, 17(1/2), 9-15. https:// doi.org/10.1108/ 02686900210412180
VanderKaay, S. (2000). Measuring the vital signs of intellectual capital. CMA Management, 74(4), 1821.

Veltri, S., \& Silvestri, A. (2011). Direct and indirect effects of human capital on firm value: Evidence from Italian companies. Journal of Human Resource Costing $\mathcal{E}$ Accounting, 15(4), 232-254. https://doi.org/10.1108/ 14013381111178596

Villalonga, B., \& Amit, R. (2006). How do family ownership, control, and management affect firm value? Journal of Financial Eco- nomics, 80(2), 385-417. https:/ /doi.org/10.1016/j.jfineco. 2004.12.005

Wahid, A. H. D. A., Abu, N. A., Latif, W. A., \& Smith, M. (2013). Corporate governance and intellectual capital: Evidence from public and private universities. Higher Education Studies, 3(1), 63-78. https://doi.org/10.5539/ hes.v3n1p63

Watts, R. L. (2006). What has the invisible hand achieved? Accounting and Business Research, 36(sup1), 51-61. https://doi. org/ $10.1080 / 00014788$. 2006.9730046 